\title{
KONSEP PENILAIAN BAGI PARA PAMONG BELAJAR DALAM RANGKA PENGENDALIAN MUTU DAN DAMPAK PROGRAM PNF
}

\author{
Ma'ruf Akbar*
}

\begin{abstract}
Learning mentor has an important role in implementing NFE programs, especially as a technical functional operator, learning model developer, instructor and evaluator. They should be able to do the evaluation in order to control the quality and the implementation impact of NFE programs.

NFE provides educational services which have to be improved continuously in the aspects of planning, implementation, learning achievment and the outcome.
\end{abstract}

Keywords: learning mentor, quality control, planning, implementation, evaluation, action analysis

\section{PENDAHULUAN}

Pendidikan nonformal merupakan upaya layanan pendidikan yang berfungsi sebagai pengganti, penambah, dan atau pelengkap pendidikan formal dalam rangka mendukung pendidikan sepanjang hayat. Implementasi fungsi tersebut menimbulkan konsekuensi logis terhadap kebutuhan peningkatan mutu sepadan dengan fungsi pendidikan formal dalam memenuhi kebutuhan pendidikan masyarakat. Berbicara tentang upaya peningkatan mutu pendidikan mencakup juga upaya peningkatan ke dua lingkup pendidikan tersebut. Dibandingkan dengan upaya peningkatan mutu layanan pendidikan pada kenyataannya pendidikan nonformal masih harus mengejar pencapaian upaya peningkatan mutu yang telah diperoleh oleh pendidikan formal, terutama dalam sumber daya manusianya, seperti guru, kepala sekolah di pendidikan formal, dan tutor dan pamong belajar di pendidikan nonformal. Sumber daya manusia yang perlu mendapat perhatian dalam upaya peningkatan mutu pendidikan di lingkup pendidikan nonformal adalah pamong belajar. Pamong belajar yang berperan dalam operasionalisasi program-program pendidikan nonformal berkedudukan sebagai pelaksana teknis fungsional, pengembang model, pengajaran, dan penilaian pada BPKB/SKB. Selain itu, juga melaksanakan penilaian dalam rangka pengendalian mutu dan dampak pelaksanaan program pendidikan luar sekolah.

Dalam rangka pengendalian mutu inilah peran pamong belajar menjadi penting untuk dijadikan bahan pembahasan. Oleh karena itu, konsep penilaian yang bagaimanakah yang mampu mendasari pemahaman pamong belajar untuk menjalankan fungsi dan tugasnya.

\section{PEMBAHASAN}

\section{Rasional Pembekalan Konsep}

Pembekalan pemahaman konsep ini berdasarkan pertimbangan yuridis yang berlaku pada saat ini dalam rangka mendukung peningkatan mutu penyelenggaraan layanan pendidikan oleh satuansatuan pendidikan luar sekolah, khususnya oleh pelaksana utama di lapangan yaitu para pamong belajar. Dasar regulasi itu adalah sebagai berikut.

1. UU No. 20 Tahun 2003 tentang Sistem Pendidikan Nasional, bahwa di Indonesia ada tiga jalur

* Dosen PLS FIP UNJ

56 Jurnal IImiah VISI PTK-PNF - Vol. 2, No.1 - 2007 pendidikan yaitu: (a) pendidikan formal, (b) pendidikan nonformal, dan (c) pendidikan informal. Pendidikan nonformal diselenggarakan bagi masyarakat yang membutuhkan layanan pendidikan yang berfungsi sebagai pengganti, penambah, dan atau pelengkap pendidikan formal dalam rangka mendukung pendidikan sepanjang hayat.

2. Pasal 26 UU No. 20 Tahun 2003 tentang Sistem Pendidikan Nasional bahwa hasil pendidikan nonformal dihargai setara dengan hasil program pendidikan formal setelah melalui proses penilaian penyetaraan oleh lembaga yang ditunjuk oleh 
Pemerintah atau Pemerintah Daerah dengan mengacu pada standar nasional pendidikan.

3. Kepmen No. 25 Tahun 1999, tentang Jabatan Fungsional Pamong Belajar dan Angka Kreditnya. Pasal 2 Bab II, bahwa pamong belajar berkedudukan sebagai pelaksana teknis fungsional pengembangan model, pengajaran, dan penilaian pada BPKB/SKB, dan Pasal 3, yaitu: (a) melaksanakan pengembangan model program pendidikan luar sekolah, pemuda dan olahraga; (b) melaksanakan kegiatan belajar mengajar dalam rangka pengembangan model dan pembuatan percontohan program pendidikan luar sekolah, pemuda dan olahraga; serta (c) melaksanakan penilaian dalam rangka pengendalian mutu dan dampak pelaksanaan program pendidikan luar sekolah, pemuda dan olahraga.

\section{Konsep Dasar Penilaian dalam Pengendalian Mutu}

Penyelenggaraan layanan pendidikan, dalam hal ini adalah pendidikan nonformal, seperti paket $A, B$, dan $C$, pada umumnya dirancang dalam suatu kemasan sistem. Sistem tersebut terdiri atas: (1) perencanaan, (2) proses penyelenggaraan, (3) hasil-hasil yang dicapai, dan (4) dampak implementasi hasil atau penerapannya di masyarakat. Masing-masing komponen sistem tersebut, saling berkaitan, dan komponen yang satu mempengaruhi komponen yang lainnya. Proses penyelenggaraan program akan bergantung pada perencanaan, dan hasil-hasil program yang dicapai bergantung pada kualitas proses penyelenggaraan program. Kualitas penerapan hasil program bergantung pada mutu hasil atau lulusan program. Empat komponen tersebut merupakan komponen penting yang tidak dapat dipisah-pisahkan, dan secara terpadu merupakan suatu kesatuan dan selayaknya menjadi perhatian utama bagi para disainer, pengelola, atau evaluator program.

Perencanaan dalam hal ini merupakan tahapan untuk identifikasi kebutuhan belajar warga belajar, kurikulum, menyusun program kegiatan pembelajaran, persiapan pembelajaran, bahan ajar, metode pembelajaran, media pembelajaran, dan alat serta teknik evaluasi. Proses penyelenggaraan merupakan tahapan proses pembelajaran sesuai dengan perencanaan pembelajaran yang telah ditetapkan. Hasil-hasil yang dicapai merupakan tahapan dan peristiwa tercapainya kompetensi pembelajaran oleh para peserta didik. Dampak implementasi hasil di masyarakat merupakan proses diterapkannya hasil-hasil pembelajaran di masyarakat.

Penyelenggaraan program layanan pendidikan sebagai suatu sistem akan menghasilkan lulusan yang berkualitas apabila dikelola secara tepat sesuai dengan konsep manajemen program yang benar. Konsep dasar manajemen program antara lain adalah bagaimana agar program tetap bermutu secara berkesinambungan/ berkelanjutan secara terkendali dalam rangka memberikan layanan pendidikan kepada masyarakat atas dasar prinsip efisiensi dan efektivitas penggunaan sumber-sumber yang ada dalam pelaksanaan program. Konsep ini merupakan konsep manajemen program yang disebut konsep kendali/pengendalian mutu (Quality Control atau QC).

Konsep mutu penyelenggaraan program minimal didukung oleh empat landasan yaitu: (1) layanan pendidikan kepada warga belajar, (2) perbaikan sistem layanan secara terus menerus/berkelanjutan, (3) mengelola program berdasarkan atas fakta/data empiris, dan (4) respek terhadap personal yang terkait dalam program. Konsep perbaikan sistem layanan pendidikan secara berkelanjutan ini dapat dilakukan melalui empat langkah yaitu:

1. perencanaan $(P)$,

2. implementasi (I),

3. evaluasi/check (EV), dan

4. analisis tindakan lanjutan $(A)$.

Perencanaan $(P)$ dalam hal ini merupakan tahapan untuk identifikasi perubahan kebutuhankebutuhan pembelajaran yang dibutuhkan warga belajar, hasil belajar, hambatan-hambatan yang perlu diatasi, menyusun perencanaan perbaikan/solusi masalah. Implementasi (I) merupakan langkah penerapan dari perencanaan. Evaluasi/check (EV) adalah merupakan asesmen (assessment) dan pengukuran efek-efek perubahan terhadap hasil pembelajaran. Analisis tindakan lanjutan (A) merupakan identifikasi apakah data hasil perbaikan sesuai dengan perencanaan, dan apakah resiko lain ada pada pelaksanaan perbaikan program ini. Kemudian atas dasar data ini dilakukan analisis tindakan lanjutan apakah kebutuhan berikut dan apakah tindakan perbaikan selanjutnya yang paling tepat untuk dilakukan. Kemudian, dilakukan analisis perencanaan lagi dan kembali lagi ke siklus seperti yang telah dijelaskan. Seluruh penjelasan tersebut dapat dilihat pada gambar 1 . 


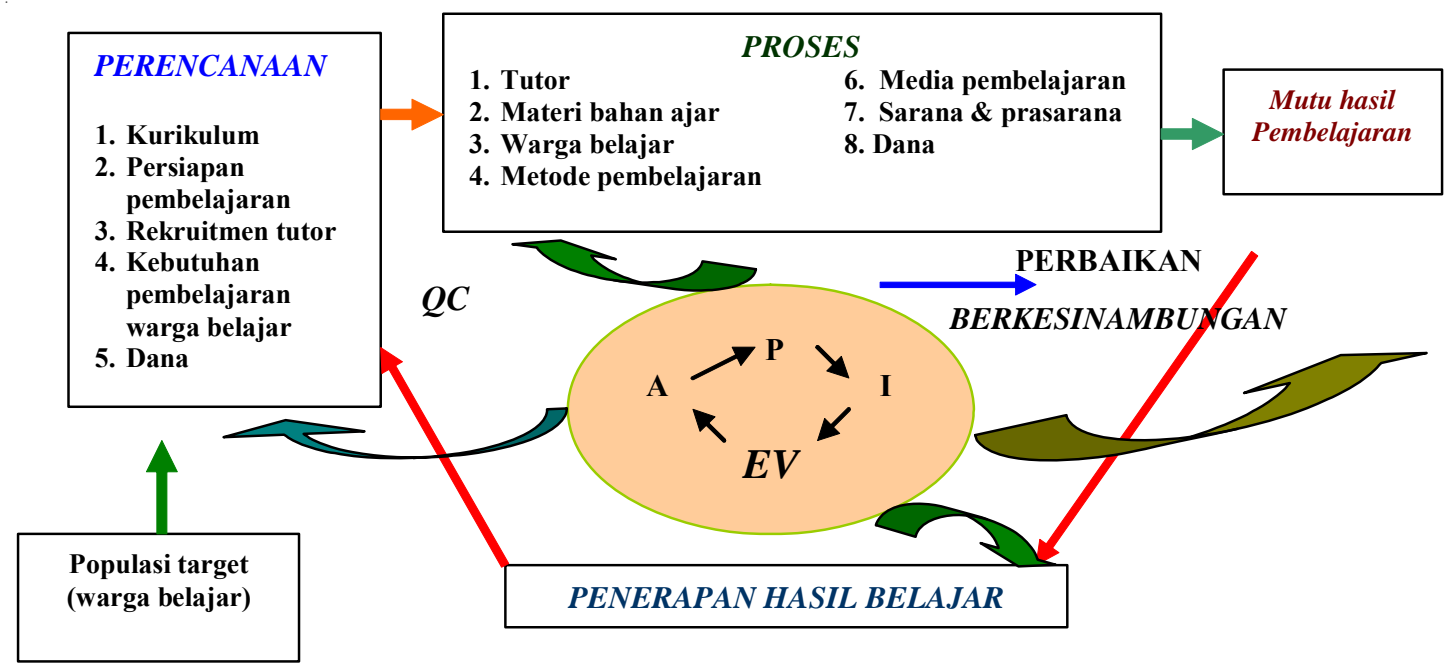

Gambar 1. Sistem penilaian pengendalian mutu layanan pembelajaran

Setiap subsistem yaitu perencanaan, proses, mutu hasil pembelajaran, dan penerapan hasil belajar membutuhkan perbaikan (secara berkesinambungan), melalui evaluasi untuk mengontrol kualitas hasilnya. Kontrol inilah yang dimaksud dengan pengendalian mutu per-subsistem dalam penyelenggaraan pendidikan nonformal oleh pamong belajar. Misalnya, dalam subperencanaan, penerapan pengendalian mutu dapat mencakup evaluasi: ketersediaan kurikulum, persiapan pembelajaran, kesiapan tutor melalui rekrutmen yang tepat sesuai dengan kriteria yang telah ditentukan, rancangan pembelajaran sesuai dengan kebutuhan warga belajar, dan ketersediaan dana pembelajaran.

Evaluasi dilakukan dengan mengumpulkan informasi secara nyata/realitas yang termasuk dalam sub komponen perencanaan tersebut kemudian dibandingkan hasilnya dengan kriteria. Jika antara hasil informasi yang dikumpulkan itu dengan kriteria terjadi perbedaan/kesenjangan yang lebar maka dipikirkan

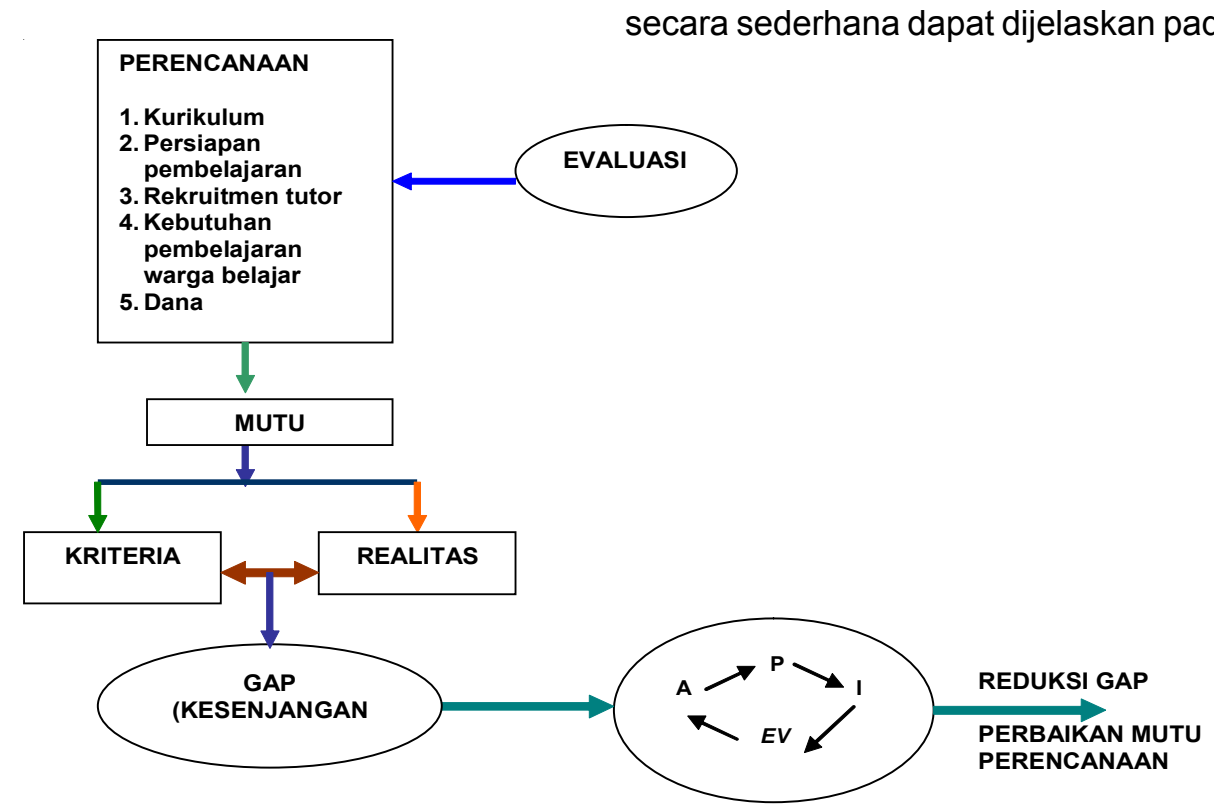

Gambar 2. Sistem penilaian pengendalian mutu layanan pembelajaran pada komponen perencanaan suatu perencanaan solusi untuk meningkatkan mutu subkomponen perencanaan tersebut. Setelah perumusan perencanaan solusi (untuk meningkatkan mutu subperencanaan tersebut, misal memperbaiki cara rekrutmen tutor), dilakukan implementasi perencanaan solusi tersebut dalam hal cara rekrutmen tutor, misal dengan cara tes dan diikuti dengan wawancara. Setelah tahapan implementasi, selanjutnya dilakukan evaluasi/cek hasil rekrutmen tutor, apakah telah memenuhi kriteria yang telah ditentukan.

Berdasarkan pada hasil evaluasi, kemudian dilakukan analisis tindakan selanjutnya untuk solusi perbaikan subperencanaan. Kemudian, dilakukan tahapan ulang seperti dalam siklus kendali mutu dalam sub-perencanaan tersebut. Tujuan dari siklus tersebut adalah untuk mengupayakan kontrol mutu sub perencanaan, sehingga antara realitas dengan kriteria mutu tidak terjadi perbedaan kesenjangan. Penerapan pengendalian mutu terhadap proses perencanaan secara sederhana dapat dijelaskan pada gambar 2 . 
Pada konsep mutu terkandung makna kriteria dan realitas objektif yang ada pada kenyataannya. Demikian pula pada perencanaan layanan program pembelajaran, ada kriteria perencanaan yang selayaknya digunakan ketika menyusun perencanaan pembelajaran seperti (minimal): (1) ketersediaan kurikulum yang lengkap, (2) ketersediaan tutor yang memenuhi persyaratan standar kompetensi sebagai tutor, (3) ketersediaan satuan persiapan/perencanaan pembelajaran yang sesuai dengan kurikulum, (4) ketersediaan data kebutuhan belajar warga belajar, (5) kesiapan warga belajar untuk mengikuti pembelajaran, (6) ketersediaan bahan ajar sesuai warga belajar, (7) ketersediaan media pembelajaran yang dibutuhkan, dan (8) dana untuk operasional penyelenggaraan pembelajaran

Namun demikian, persyaratan unsur-unsur yang ada dalam perencanaan tersebut, pada pelaksanaannya belum tentu semuanya ada, dan tidak sesuai dengan kriteria yang ada. Dengan demikian, perlu dilakukan suatu perencanaan perbaikan mutu aspek perencanaan, melalui langkah-langkah PIEVA: (1) perencanaan, (2) implementasi perencanaan, (3) evaluasi hasil, dan (4) analisis tindakan selanjutnya. Kontrol mutu ini dilakukan secara kontinyu sehingga sampai pada titik tercapainya perbaikan/peningkatan mutu. Penerapan pengendalian mutu terhadap proses pembelajaran secara sederhana dapat dijelaskan pada gambar 3 .

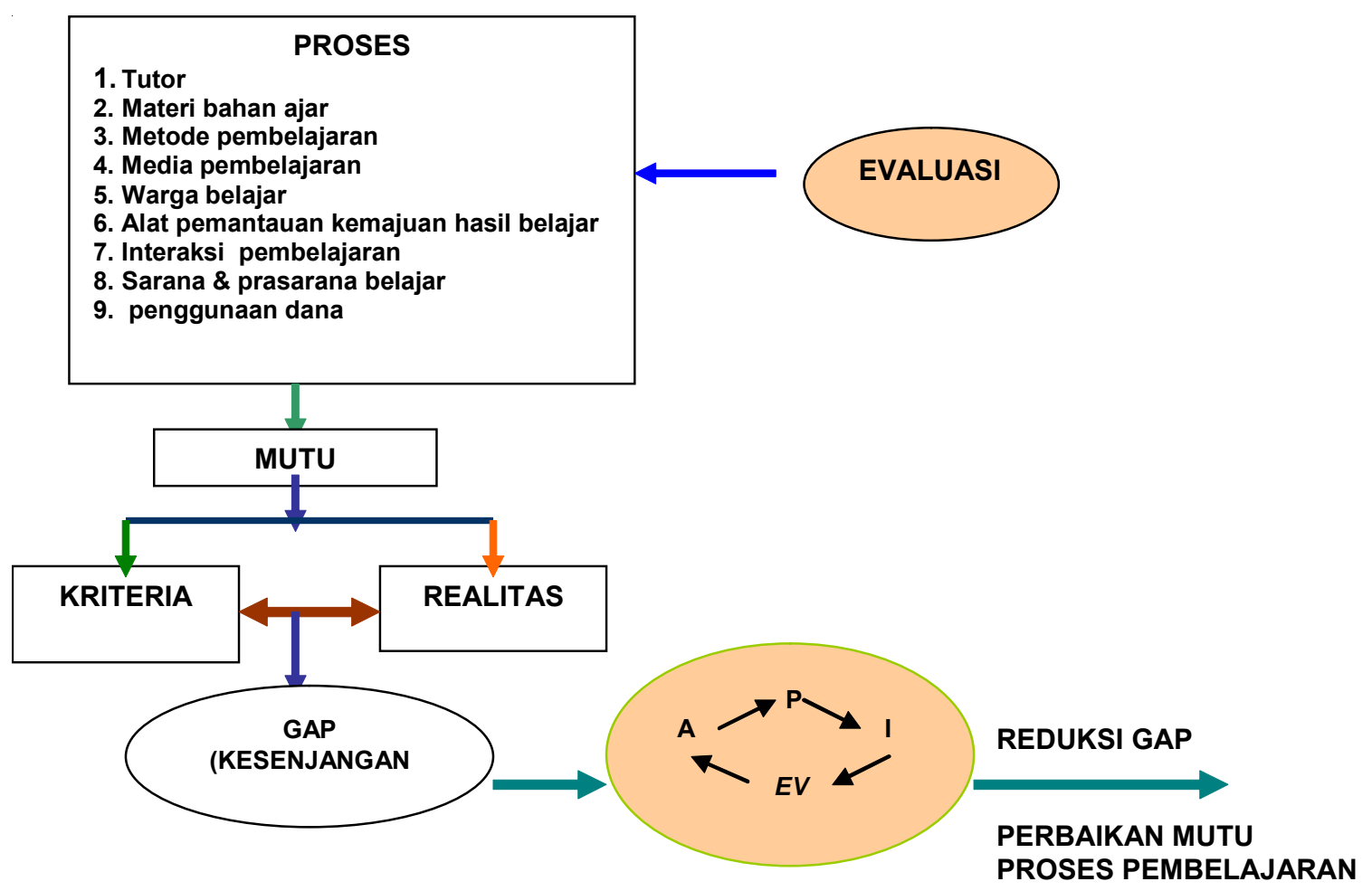

Gambar 3. Sistem penilaian pengendalian mutu layanan pembelajaran pada komponen proses perencanaan

Sama dengan penjelasan aspek perencanaan sebelumnya, dalam komponen proses pembelajaran juga konsep mutu terkandung makna kriteria dan realitas objektif. Pada aspek proses layanan pembelajaran, ada kriteria yang selayaknya digunakan ketika melakukan proses layanan pembelajaran, yaitu (minimal): (1) kesiapan tutor untuk memberikan layanan pembelajaran, (2) ketersediaan bahan ajar yang memenuhi persyaratan standar substansi isi dan sesuai dengan kompetensi yang dituntut dalam kurikulum, (3) kesiapan rancangan metode pembelajaran sesuai dengan satuan persiapan/perencanaan pembelajaran yang sudah disiapkan, (4) ketersediaan dan kesiapan media pembelajaran sesuai dengan yang telah direncanakan, (5) kesiapan warga belajar untuk mengikuti proses pembelajaran, (6) ketersediaan alat pemantauan kemajuan hasil belajar, (7) terjadinya proses belajar aktif, (8) ketersediaan sarana dan prasarana pendukung proses pembelajaran, dan (9) penggunaan dana untuk operasional penyelenggaraan pembelajaran yang efektif.

Namun demikian persyaratan unsur-unsur yang ada dalam perencanaan, pada kenyataannya belum tentu semuanya ada, dan tidak sesuai dengan kriteria 
yang ada. Dengan demikian perlu dilakukan suatu perencanaan perbaikan mutu aspek proses pembelajaran, melalui langkah-langkah PIEVA: (1) perencanaan $(P),(2)$ implementasi perencanaan (I), (3) evaluasi hasil (EV), (4) analisis tindakan selanjutnya
(A). Kontrol mutu ini dilakukan secara kontinyu sehingga sampai pada titik tercapainya perbaikan/ peningkatan mutu pada proses layanan pembelajaran. Penerapan pengendalian mutu terhadap hasil pembelajaran dapat dilihat pada gambar 4.

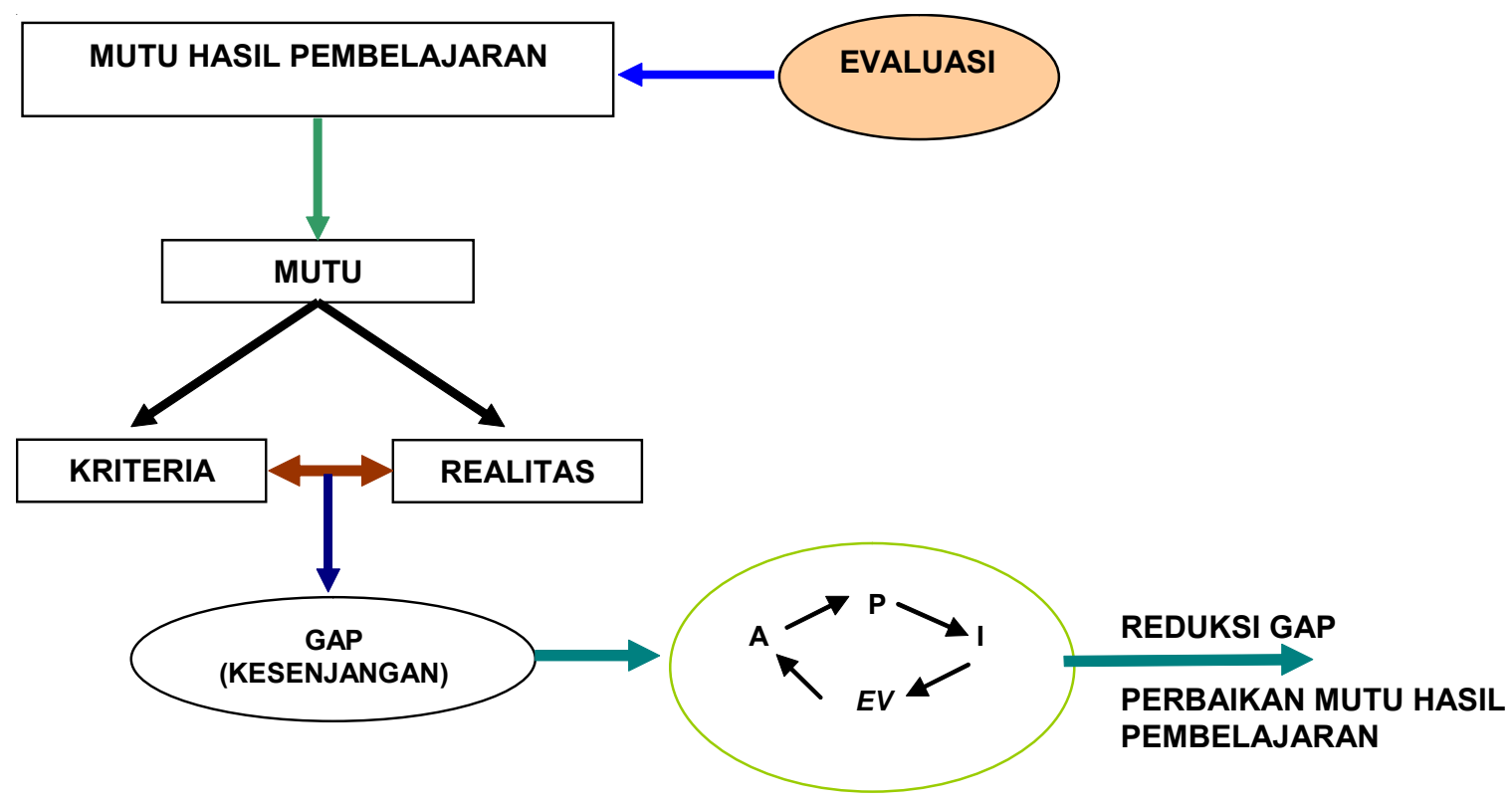

Gambar 4. Sistem penilaian pengendalian mutu layanan pembelajaran pada komponen hasil pembelajaran

Sama dengan penjelasan aspek hasil pembelajaran sebelumnya, dalam komponen proses pembelajaran juga konsep MUTU terkandung makna kriteria dan realitas objektif. Pada aspek hasil pembelajaran, ada kriteria yang selayaknya digunakan ketika meninjau hasil pembelajaran, yaitu (minimal): (1) pencapaian hasil belajar di atas kriteria (standar minimal), (2) pencapaian rata-rata hasil penyelesaian tugas-tugas pembelajaran di atas kriteria (standar minimal), dan (3) pencapaian hasil belajar hasil ulangan/ tes di atas kriteria (standar minimal).

Namun demikian persyaratan unsur-unsur yang ada dalam perencanaan tersebut, pada kenyataannya belum tentu semuanya ada, dan tidak sesuai dengan kriteria yang ada. Dengan demikian perlu dilakukan suatu perencanaan perbaikan mutu aspek hasil pembelajaran, melalui langkah-langkah PIEVA: (1) perencanaan $(P),(2)$ implementasi perencanaan (I), (3) evaluasi hasil (EV), dan (4) analisis tindakan selanjutnya (A). Kontrol mutu ini dilakukan secara kontinyu sehingga sampai pada titik tercapainya perbaikan/peningkatan mutu hasil pembelajaran.

\section{Evaluasi Dampak Program}

Suatu program layanan pendidikan sesungguhnya merupakan suatu intervensi yang terencana terhadap suatu populasi target sasaran yang diharapkan melalui layanan program pendidikan tersebut akan terjadi sejumlah perubahan yang mampu mengangkat mereka menjadi lebih baik dalam status sosialekonominya. Suatu program memiliki tugas-tugas khusus dan kriteria keberhasilan tertentu. Fungsi program sebenarnya mengadakan perubahanperubahan perilaku yang sesuai dengan arah perubahan yang diharapkan yaitu perilaku-perilaku cerdas yang terdidik. Untuk mengetahui sejauh mana program layanan pembelajaran dapat memunculkan perubahanperubahan demikian maka dilakukan Evaluasi Dampak Program (Impact Evaluation atau EDP). Hasil EDP dapat berupa temuan bahwa intervensi layanan program mampu menimbulkan perubahan-perubahan perilaku terdidik sesuai kriteria keberhasilan dan tujuan program atau tidak mampu menimbulkan hal demikian. Secara bagan penjelasan ini dapat dilihat pada gambar 5 di halaman berikut. 


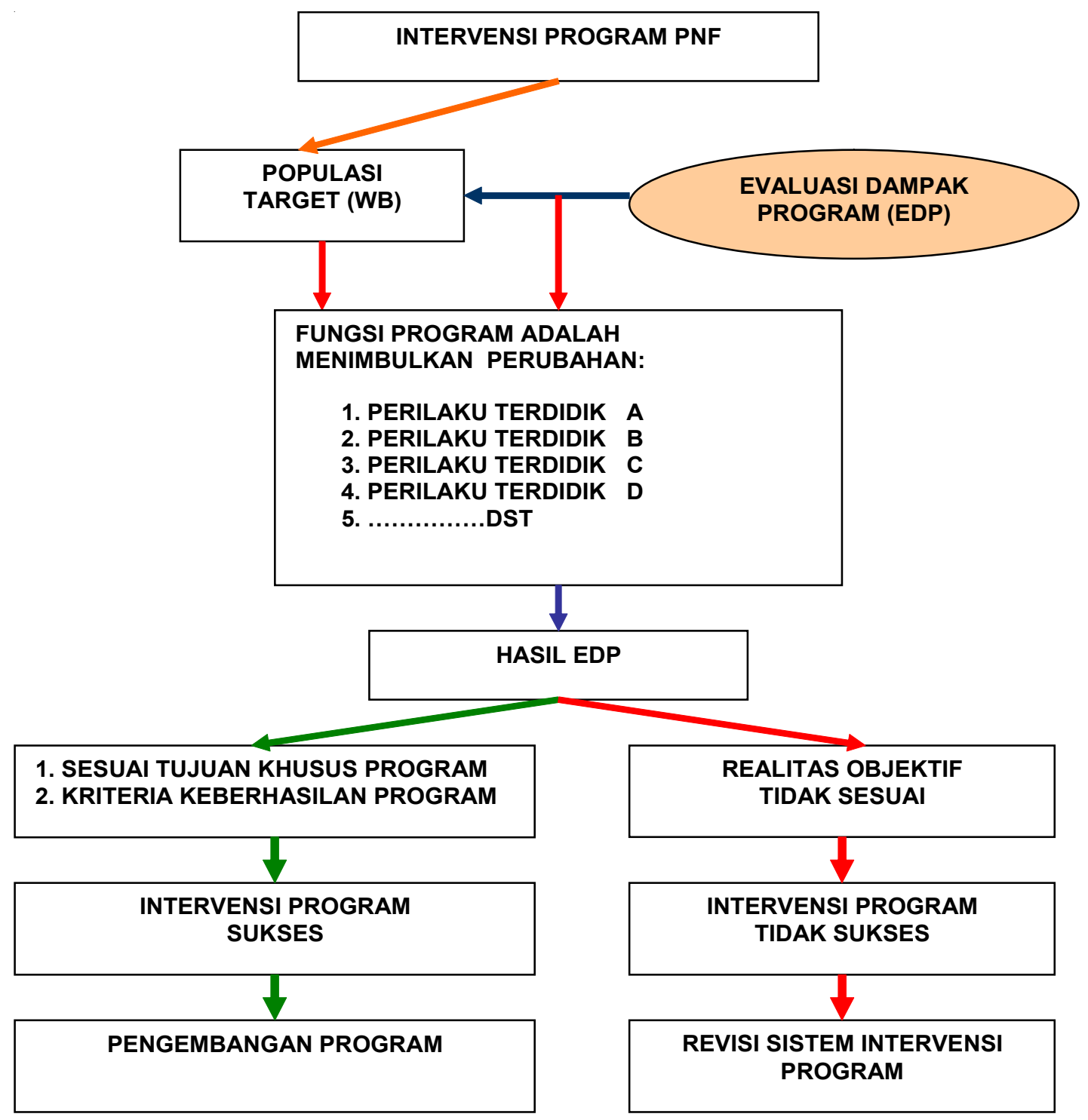

Gambar 5. Contoh penerapan evaluasi dampak program pada program layanan PNF

\section{Strategi Penilaian}

Strategi penilaian memiliki makna bahwa dengan sumber-sumber yang ada dan dapat digunakan kita dapat melakukan penilaian dengan cara yang efektif dan efisien yang sesuai dengan rambu-rambu penilaian dan hasilnya dapat dipercaya dan evaluasi tersebut dapat diulang oleh pihak lain (dengan hasilnya sama).

Penilaian dalam rangka pengendalian mutu dan dampak pelaksanaan program layanan pembelajaran dalam PNF dapat meliputi empat tahapan: (1) persiapan, (2) penilaian, (3) pengolahan hasil penilaian, dan (4) pelaporan Hasil penilaian.

Sebelum melakukan penilaian perlu dilakukan persiapan yang cermat yang mencakup: bagaimana rancangan penilaian, instrumen pengumpulan data penilaian, dan bagaimana uji coba instrumen pengumpulan datanya.
Pelaksanaan penilaian mencakup: melaksanakan orientasi petugas penilaian (sebagai responden/ subjek yang dinilai, dan sebagai petugas pengumpul data), dan melakukan pengumpulan data ke lapangan. Sedangkan pengolahan hasil penilaian mencakup: mengolah dan menganalisis data hasil penilaian, serta menyajikan temuan analisis data. Sementara itu, pelaporan hasil penilaian mencakup: menyusun konsep laporan hasil penilaian, menyempurnakan konsep laporan penilaian, menyusun laporan akhir penilaian.

\section{Persiapan Penilaian}

Pada tahap persiapan penilaian, yang pertama dilakukan adalah menyusun rancangan penilaian dari menentukan sasaran/objek evaluasi sampai dengan metode pelaporan hasil evaluasi seperti tampak pada tabel 1 di halaman berikut. 
Tabel 1. Penyusunan rancangan penilaian

\begin{tabular}{|c|l|l|}
\hline No. & \multicolumn{1}{|c|}{ Aspek rancangan } & \multicolumn{1}{c|}{ Keterangan } \\
\hline 1. & Sasaran/Objek Evaluasi & Apa yang akan dievaluasi \\
\hline 2. & Tujuan Evaluasi & Maksud evaluasi, dan alasannya \\
\hline 3. & $\begin{array}{l}\text { Pertanyaan Evaluasi (dan sub- } \\
\text { sub pertanyaan evaluasi, jika } \\
\text { dibutuhkan) }\end{array}$ & $\begin{array}{l}\text { Pertanyaan-pertanyaan yang penting dan kemengapaan- } \\
\text { nya, tentang ciri dan nilai objek/sasaran evaluasi yang } \\
\text { harus dijawab melalui temuan data dan informasi dari } \\
\text { lapangan }\end{array}$ \\
\hline 4. & Data yang dibutuhkan & $\begin{array}{l}\text { Data yang harus dikumpulkan untuk menjawab } \\
\text { pertanyaan evaluasi }\end{array}$ \\
\hline 5. & Metode pengumpulan data & Cara yang digunakan untuk mengumpulkan data \\
\hline 6. & Instrumen pengumpulan data & Alat-alat untuk mengumpulkan data \\
\hline 7. & Metode analisis data & $\begin{array}{l}\text { Cara yang digunakan untuk analisis data yang } \\
\text { mengarahkan evaluator menjawab pertanyaan evaluasi }\end{array}$ \\
\hline 8. & Kesimpulan dan Penafsiran & $\begin{array}{l}\text { Kesimpulan dan Penafsiran yang mengarah kepada } \\
\text { maksud dan tujuan evaluasi }\end{array}$ \\
\hline 9. & $\begin{array}{l}\text { Metode pelaporan hasil } \\
\text { evaluasi }\end{array}$ & Cara melaporkan hasil-hasil evaluasi \\
\hline
\end{tabular}

Rancangan ini dibutuhkan untuk memudahkan pamong belajar melaksanakan persiapan, penilaian, serta pelaporan hasilnya. Rancangan ini diikuti pula dengan menyusun tahapan menyusun instrumen pengumpulan data penilaian dan uji coba, seperti tampak pada tabel 2.

Tabel 2. Tahapan menyusun instrumen pengumpulan data penilaian

\begin{tabular}{|c|l|l|}
\hline No. & \multicolumn{1}{|c|}{$\begin{array}{c}\text { Tahapan menyusun } \\
\text { instrumen }\end{array}$} & \multicolumn{1}{c|}{ Keterangan } \\
\hline 1. & Tabel spesifikasi & Kisi-kisi pengembangan instrumen \\
\hline 2. & $\begin{array}{l}\text { Jenis-jenis instrument dan } \\
\text { format }\end{array}$ & $\begin{array}{l}\text { Jenis-jenis instrument (angket, tes, check list, rating } \\
\text { scale, pedoman observasi, pedoman wawancara, } \\
\text { dst.) }\end{array}$ \\
\hline 3. & Draft instrumen & Menyusun draft instrumen \\
\hline 4. & Uji coba & Uji coba validasi dan reliabilitas \\
\hline 5. & Revisi & Revisi instrument \\
\hline 6. & $\begin{array}{l}\text { Persiapan penggunaan } \\
\text { instrumen }\end{array}$ & Penggandaan instrumen \\
\hline
\end{tabular}

\section{Pelaksanaan Penilaian}

Sebelum melakukan pengumpulan data penilaian, evaluator melakukan orientasi terhadap personal yang mencakup penentuan/penetapan personal: (1) sebagai responden/subjek yang dinilai/sumber informasi, dan (2) pengarahan petugas pengumpul data, tentang petunjuk dan penggunaan instrumen atau teknik pengumpulan data.

Setelah melakukan orientasi maka dilakukan pengumpulan data ke lapangan. Biasanya pekerjaan ini dilakukan oleh petugas pengumpul data.

\section{Pengolahan Hasil Penilaian}

Pengolahan hasil penilaian mencakup: mengolah dan menganalisis data hasil penilaian, dan menyajikan temuan analisis data.

62 Jurnal IImiah VISI PTK-PNF - Vol. 2, No.1 - 2007

\section{Pelaporan Hasil Penilaian}

Pelaporan hasil penilaian mencakup tahapan:

1. menyusun konsep laporan hasil penilaian,

2. menyempurnakan konsep laporan penilaian, dan

3. menyusun laporan akhir penilaian. Isi laporan hasil penilaian pada umumnya berisikan unsur-unsur berikut.

I. PENDAHULUAN
A. Rasional
B. Tujuan Penilaian
C. Pertanyaan Evaluasi
D. Hasil yang Diharapkan

II. PERENCANAAN DISAIN PENILAIAN
A. Sasaran/Objek Penilaian
B. Pertanyaan-Pertanyaan Penilaian
C. Data yang Dibutuhkan
D. Metode Pengumpulan Data 


\author{
E. Instrumen Pengumpulan Data \\ F. Uji Coba, Validasi dan Reliabilitas Instrumen \\ G. Metode Analisis Data \\ H. Pelaporan Hasil Penilaian \\ III. ANALISIS DATA, TEMUAN HASIL PENILAIAN, \\ DAN PEMBAHASAN
}

A. Deskripsi Data
B. Analisis Data
C. Kesimpulan dan Penafsiran
D. Pembahasan
E. Rekomendasi

\section{LAMPIRAN}
Instrumen
Bukti (sampel) data lapangan

\section{KESIMPULAN}

Peningkatan mutu sumber daya manusia dalam rangka penyelenggaraan layanan pendidikan nonformal dapat dilakukan dengan meningkatkan kemampuan konseptual dan teknis tentang penilaian dalam rangka penerapan dan pelaksanaan pengendalian mutu program-program pendidikan nonformal di masyarakat, khususnya oleh para pamong belajar. Konsep ini terkait secara integral dengan upaya efisiensi dan efektivitas mulai dari perencanaan sampai dengan dampak program, dan dilakukan secara kontinyu, untuk mendapatkan optimalisasi pemenuhan kebutuhan masyarakat terhadap layanan pendidikan nonformal.

\section{DAFTAR PUSTAKA}

Aiken, L. R. (1996). Rating scales and checklists evaluating behavior personality and attitude. Singapore:John Wiley Sons, Inc.

Brinkerhoff, R. O (1983). Program evaluation: A practitioner's for trainer and educators. Boston: Kluwer-Nijhoff Publishing.

Kirkpatrick, H., Donald L., \& Kirkpatrick, J. D. (2006). Evaluating training programs. San Francisco: BKPublishers, Inc

Lewis, R. G. \& Smith, D. H. (1994). Total quality in higher education. Florida: St. Lucie Press.
Madaus, G. F., Scriven, Michael S., \& Stufflebeam, D. L. (1983). Evaluation models viewpoints on educational and human services evaluation. Boston: Kluwer-Nijhoff Publishing

Philips, J. J., \& Stone, R. D. (2002). How to measure training results. San Francisco: McGraw

Rossi, P. H., \& Freeman, H. E. (1993). Evaluation: A systematic approach. London: Sage Publications.

Sergiovanni, T. J., \& Starratt, R. J. (2002). Supervision: A redefinition. Boston: Mc Graw Hill. 